\title{
Teaching Competency, Professional Commitment and Job Satisfaction-A Study of Primary School Teachers
}

\author{
Shashi Shukla \\ Miranda House, University of Delhi
}

\begin{abstract}
Education leads to change... a change towards growth, a change in thinking and a change in positive direction. It's the key to human progress and teacher plays the most crucial role in the system of education. The teacher is regarded as the foundation on which the stability of the educational system as well the nation rests. The commitment and competency of teacher is considered to be associated with his satisfaction with the job, attitude towards the profession etc.
\end{abstract}

Keywords: Education, Job satisfaction, Professional development, Teachers, Teaching competency

\section{Introduction}

Education is the only instrument to make preamble true and only means for desirable social change. Article 1 of the Declaration of Human Rights (1948), adopted by UN says, "All human beings are born free and equal in dignity and rights. They are endowed with reason and conscience and should act towards one another in a spirit of brotherhood". The importance of education is quite clear. Education is the knowledge of putting one's potentials to maximum use. One can safely say that a human being is not in the proper sense till he is educated. The quality of a nation depends upon the quality of its citizens. The quality of the citizens rests upon the quality of their education. the quality of their education depends upon the competence, dedication and quality of school teacher sit is not brick ad mortar of the classroom, but the dialogues rapport and interactions supported by deeds, between the learners and the teachers, all the time developing within its four walls can make or mar the destiny of the youngsters and in turn that of the nation.

This importance of education is basically for two reasons. The first is that the training of a human mind is not complete without education. Education makes man a right thinker. It tells man how to think and how to make decision. The second reason for the importance of education is that only through the attainment of education, man is enabled to receive information from the external world; to acquaint him with past history and receive all necessary information regarding the present. Without education, man is as though in a closed room and with education he finds himself in a room with all its windows open towards outside world. Education is thus the starting point of every human activity.

A scholar (alim) is accorded great respect in the hadith. According to a hadith the ink of the pen of a scholar is more precious than the blood of a martyr. The reason being that a martyr is engaged in defense work while an alim (scholar) builds individuals and nations along positive lines. In this way he bestows a real life to the world. How great importance is attached to learning in Islam can be understood from an event in the life of the Prophet. At the battle of Badr in which the Prophet gained victory over his opponents, seventy people of the enemy rank were taken prisoner. These prisoners of war were literate people. In order to benefit from their education the Prophet declared that if one prisoner teaches ten Medinan children how to read and write, this will serve as his ransom and he will be set free. This was the first school in the history of Islam established by the Prophet himself with all its teachers being non-Muslims. Furthermore, they were all war prisoners. Education plays the critical role in the development and growth of human beings which in turn marks the progress of the human society. Education empowers the individuals to be self-dependent and enlighten their vision of life thus improving the quality of life. Education is a process of human enlighten and empowerment for the achievement of a better and higher quality of life. A sound and effective system of education results in the enfoldment of learners' potentialities, enlargement of their competencies and transformation of their interests, attitudes and values.

\subsection{Role of the Teacher}

The source of true and holistic education is the teacher. Teacher in Indian heritage has always been given a raised platform of respect. Apart from imparting education to children, the teacher has been a friend, guide and philosopher. Teachers are regarded as the most powerful agents' of social change. According to Swami Vivekananda, "Education is the manifestation of the perfection already in men." Education alone makes a man perfect and all round development of human personality is possible through education. Professor Linda Darling-Hammond of Stanford University has summarized research on the effects of teacher quality on student outcomes as follows: 
The effect of poor quality teaching on student outcomes is debilitating and cumulative. The effects of quality teaching on educational outcomes are greater than those that arise from students' backgrounds. A reliance on curriculum standards and statewide assessment strategies without paying due attention to teacher quality appears to be insufficient to gain the improvements in student outcomes sought .The quality of teacher education and teaching appear to be more strongly related to student achievement than class sizes, overall spending levels or teacher salaries (Darling-Hammond 2000).

Teachers shoulder the responsibility of shaping the future of the nation. The future of the nation depends upon the skills and efficiency of the teachers. Teachers are given the other name as creators....they are the creators of philosophers, leaders, doctors, advocates and many more. A teacher's job is not at all that easy and unless a high degree of professional qualities and commitment are inculcated in the teacher's personality, the training program would remain incomplete. Teachers work involves rigorous efforts in the classroom and outside as well as frequent interaction with parents and community members. For this purpose teacher's need to be well trained and competent to perform their jobs. If teachers acquire Professional competencies and commitment and if they are enabled and empowered to perform their multiple tasks in the classroom as well as in the school and community in a genuinely professional manner, then a high quality learning among increasing more students may result in cognitive, affective and psychomotor areas of human development improving teaching performance through more effective teacher preparation, therefore is an essential ingredient in solving most educational problems. Educationist all over the world have started realizing that only securing enough teachers will not do, most important is securing the right type of teachers with right type of knowledge, skills, attitudes and competence. Due to this increased stress is being laid on the qualitative aspect of the teacher education. It is being realized now that efficient and competent teacher is major factor that will contribute to educational refinement and improvement and the search is on for those factors that make the teachers competent. According to the Programme of Action (1992), "Teachers are supposed to look after the development of children and their performance is the most crucial input in the field of education, thus their training should be adequate to stimulate the socio-cultural and moral development of the child." Society needs such teachers who can make education vibrant and production oriented, the teachers who possess professional commitment and selfless devotion. With time the concept of teaching and position of the teacher changed with the altered values and views of life. The increasing complexity of our educational system has given rise to new dimensions and consequently the role of the teacher increased immensely and has acquired a new meaning. Teachers are the most important assets for any educational system. They are the founders, creators and executers of the educational system. Teachers are expected to fulfill all the basic requirements of the teaching learning situations, to make the learning situations pupil friendly and pronounce all possible efforts to make learning possible in a healthy way. Teachers' attitudes more generally may diminish or increase the problem of underachievement. The role of the teacher is crucial in helping pupils develop a positive attitude to learning

\subsection{Role of Primary Education:}

Primary education is the largest sub sector of any education system and offers the unique opportunity to contribute to the transformation of societies through education of the young. Since the World Education for All Conference that was held in 1990, Jomtien Thailand, primary education enrolment has expanded in absolute terms. However, the quality of primary education has not kept abreast of the expansion in enrolment. Thus universal quality primary education continues to be a global concern and was high on the agenda for the World Education Forum that was held in April 2000 in Dakar, Senegal. The resulting Dakar Framework for Action, item 7 (ii) states "Ensuring that by 2015 all children, with special emphasis on girls and children in difficult circumstances, have access to and complete free and compulsory primary education of good quality". The reality is that there are over 100 million children out of school and of those in school, a substantial proportion of them either do not complete the cycle or leave without being permanently literate and numerate. Therefore primary education continues to be a priority for all.

\subsection{Role of Teacher in Primary Education}

Primary education is the stepping stone for the progress of the educational system in the country. To make primary education strong and to empower whole nation there is a rising need of well trained teachers who are competent and committed. Teachers are facing several problems today which need to be focused and worked upon as a holistic effort of the community. Teachers need satisfying and gratifying environment to perform their level best. As it is the teachers' job to mould the children in socially acceptable way, it is the job of society and state to raise the socio economic status of teachers and give them the respected position which they deserve. Teachers are entrusted by the community to shoulder the crucial responsibility of shaping the present generation for the future through the process of teaching and learning. Teachers can act as trail blazers in the lives of learners and in the process of education for development. If the teachers acquire professional competencies and commitment and if they are enabled and empowered to perform their multiple tasks in the classroom as well as 
in the school and community in a genuinely professional manner, then the chain reaction can begin - starting with a sound teacher performance and culminating into high quality learning among increasingly more students in cognitive, affective and psychomotor domains of human development.

\subsubsection{Teaching Competency}

Teaching competencies include the acquisition and demonstration of the composite skills required for student teaching like introducing a lesson, fluency in questioning, probing questions, explaining, pace of lesson, reinforcement, understanding child psychology, recognizing behavior, classroom management and giving assignment. Competency development must a continuous process in the organization. Encyclopedia Dictionary of Education (vol.1: 1997) describes teaching competency as the state of having demonstrating skills, abilities or aptitudes in the satisfactory execution of a learning task. Encyclopedia of teacher training and education (vol.ii 1998) defines teaching competency as suitable or sufficient skill, knowledge and experience for teaching purpose, properly satisfied. As defined by B.K.Passi and M.S.Lalitha , "teaching competency means an effective performance of all observable teacher behavior that brings about desired pupil outcomes." S.Venkataiah (2000), defines, "Teaching Competency as any single knowledge, skill or professional expertise which (1.) a teacher may be said to posses and (2) the possession of which is believed to be relevant to the successful practice of teaching." Halls \& Jones (1976), defines competencies as "composite skills, behavior or knowledge that can be demonstrated by the learner and desired from explicit conceptualization of the desired outcomes of learning competencies are states so as to make possible the assessment of student learning through direct observation of student behavior." Walker (1992), developed the following definition of competence, "the attributes (knowledge, skills and attitudes) which enable an individual or group to perform a role or set of tasks to an appropriate level or grade of quality or achievement (i.e. an appropriate standard) and thus make the individual or group competent in that role."In the consultations initiated by NCTE at several national seminars the following ten inter related categories of competencies have emerged quite prominently:

- Contextual competencies include not only educational but social and cultural systems also. It includes dealing with problems of wastage and stagnation, diversities in society, developing cohesive society and issues like urbanization and value inculcation

- Conceptual competencies include knowledge about stages of child development, right perspective toward education and implications of education

- Content competencies include joyful activities, media intervention, individual learning and provision of enriched environment for learning

- Transactional competencies include planning of action and evaluation, inclusion of activities like story telling, singing etc in teaching process

- Competencies related to other educational activity include human values, celebration of national events and community life activities

- Competencies to develop teaching learning material include innovative ways to teaching and local visits to banks and other community resources

- Evaluation competencies include positivistic evaluation process, importance of feedback etc.

- Management competencies include skills of classroom management and role and responsibilities of teacher

- Competencies related to working with parents include role of parents and requirement of their cooperation in teaching learning process

- Competencies related to working with community and other agencies include the knowledge about importance of community in the holistic development of students

The competency based approach teacher education, on its being translated into actual practice will lead in improving not only the performance of the teachers but would also help them raise their status in society.

\subsubsection{Professional commitment}

Teaching is classified as profession. Teaching is no simply an occupation aimed at making money for livelihood but it is a social service for national development. A teacher should be permanently committed to his work. Those who have chosen teaching as profession, acquire necessary knowledge and skills with no personal likes and dislikes. Professional commitment means, "The feeling of dedication among the individuals of a group towards their profession." This commitment area involves tow essential components namely-pride in one's being in the teaching profession and a strong desire for professional development. In fact after joining the profession they should fully understand as long as they are there they have to develop pride knowing that this is a Nobel profession charged with great responsibilities as the society hands over its children to this system for their wholesome education. Teachers' total involvement and devotion is must for empowering the students. During and even after school hours, a committed teacher's mind remains always occupied with thoughts of children, their growth, individually as well as collectively and improvement of their performance. Committed 
teachers not only seek all round development of children put to their charge but also work hard for their own professional growth to contribute their best to the profession as teachers. They observe professional ethics befitting the nobility of the profession. Teachers' tolerance, humility and modesty could endear them to their pupils, to the community and the parents alike, thus enhancing their confidence in the total process of education. These qualities when considered along with the professional competencies of teachers would ensure their commitment and dedication to the profession at their very best. It would provide equality of opportunity and equality of success for all the learners. Rogers( 1969), described commitment as ' total organismic direction involving not only the conscious mind but the whole direction which is gradually achieved by the individual through a close relationship in which even unconscious tendencies are as much respected as conscious choices.' Commitment is a state of attachment that defines the relationship between an actor (an individual, a group or organization) and an entity (commitment target). Commitment can result from decisions. Commitment is a process. In this process, one decides among the alternatives of which he or she is aware, or has alternatives selected by others. After the decisions or selection is made, the commitment is pursued with some degree of commitment strength, through pertinent situations, and until that commitment is dropped.

\section{Areas of commitment}

- Commitment to the learner- children need teacher who understand them and their needs with sensitivity. They need to be looked after by teachers who understand their instincts, learning needs and tendencies along with their capacities and abilities. By taking up the profession of teaching, the teacher is pledged to progress and development of learners

- Commitments to the society- The school and community have symbolic relation between them. Teachers need is to orient community towards the importance of education as a life long process and also motivate them to take it in that perspective. Teachers need to have deep concern and commitment towards the community

- Commitment to the profession- Teachers are entrusted by the community to shoulder the responsibility of shaping the present generation for the future through the process of teaching and learning. Committed professionals should adopt various innovative method of teaching taking into consideration how best to learn and bring about the effective learning. This can happen only when teachers themselves show commitment to the profession to improve both guided as well as self-directed learning

- Commitment to the attaining excellence for professional actions- teachers who continue their search for becoming better human beings and better teachers are followed in their footsteps by the learners. They get all the respect from them and at the same time acquire higher levels of excellence and proficiency

- Commitment to basic values- every community expects the teachers to follow a value based approach in their personal life so as to become role models for the future generation

\subsubsection{Job Satisfaction}

Job satisfaction has been made up of two words-job and satisfaction. Job satisfaction may be defined as an attitude, which results from balancing and summation of many specific likes and dislikes, experienced in connection with the job. Job satisfaction in the result of various attitudes possessed by an employee towards his job. These attitudes are related with specific factors such as salary, service condition, opportunity, working condition and colleague.The term job satisfaction was brought to limelight by Hoppock (1935), according to him job satisfaction 'is any combination of psychological, physiological and environmental circumstances that causes a person truthfully to say, I am satisfied with my job.'

\section{Factors conducive to job satisfaction:- \\ i. Mentally challenging work \\ ii. Working conditions \\ iii. Work group \\ iv. Supervision \\ v. Incentives and rewards}

Professional competency alone does not result in effective performance. Teacher effectiveness is not automatically ensured by professional competencies and practical skills only. Well trained and effective teachers are those who are both competent and committed professional practitioners. Teachers have to acquire different skills and abilities to make their teaching competent. Job satisfaction is must for all professionals to be competent. Being the most essential asset of the society it is mandatory that teachers' job satisfaction should be ensured. When teachers are satisfied with their service conditions, status and other essential factors affecting their duties with full integrity and devotion. The education commission (1966) states, "Dissatisfaction of the individual, whatever may be the occupation in which he is engaged, results in professional stagnation. A 
dissatisfied teacher is lost not only to himself but also to the entire society. A dissatisfied teacher spells disaster to the country's future. Dissatisfaction among the workers is undesirable and dangerous in any profession; it is suicidal if it occurs in the teaching profession."

\subsection{Factors influencing job satisfaction (Fig.1)}

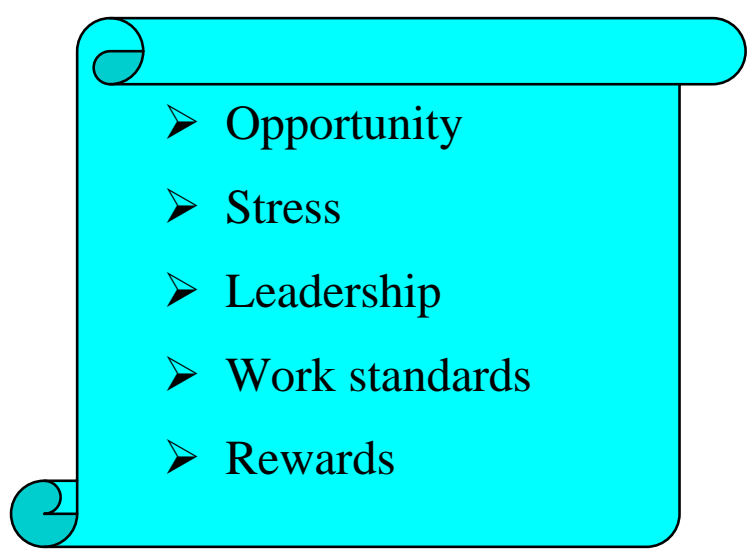

\subsection{Relationship between teaching competency, professional commitment and job satisfaction}

All teachers are not fully competent and skilled to perform their duties. This can be seen in relation to their job-satisfaction. A teacher who will be satisfied with his or her job will put in the best efforts to be competent and thus proving self as professionally committed. A committed teacher can be effective and successful by not only helping the students to realize their full potential but also helping the society to develop a sense of belonging amongst its members. Teachers who will be satisfied will always work and try to improve his teaching.

\subsection{Need and significance of the study}

Education is the key which helps to eradicate all kinds of social evils. Primary education is as necessary for the development of the country as much is the requirement of bread, cloth and home. To make primary education foundation of the education system there is requirement of competent and committed teachers and this is possible only when society and state makes an effort to provide conducive working environment for primary school teachers. A committed employee is an asset of any organization and occupies the most important place in an educational institution because they are in charge of the future of the nation. Need of the nation is not only to attract but also to retain committed teachers. Provision of facilitating working conditions for teachers will help in the enhancement of their commitment to the profession. Need of strong and empowered primary education system is well defined for a developing nation like our's. To prove the strength of our educational system we require teachers who are trained, and who are aware of their duties thus they will perform their jobs with the best they can afford. Job satisfaction affects various components of a job and is influenced by many other components as well. In the present study, efforts have been made to study the teaching competency and professional commitment in relation to job satisfaction of primary school teachers in private and government schools.

\subsection{Statement of the problem}

Teachers are the builders of nation's future. The capability of teachers is most important aspect for any country and its people. The researcher of the present study wants to study the skills of primary school teachers as primary education acts as the building block of the education system.In the present study the researcher is interested in studying the three different aspects of teaching that is Teaching Competency, Professional Commitment and Job Satisfaction among primary school teachers in two types of school- Private and Government. The two different types of school is taken as to see if any difference arises in attainment of above described aspects due to the working environment or not. The researcher will study all three aspects independently and then in relation with each other so as to see the influence of all three interchangeably "A study of Teaching Competency and Professional Commitment of Primary school teachers in relation to their Job Satisfaction."

\section{Objectives}

1. To construct a tool to measure teaching competency of primary school teachers.

2. To find relationship between teaching competency and job satisfaction among primary school teachers. 
3. To find relationship between professional commitment and job satisfaction among primary school teachers.

4. To fine relationship between teaching competency and professional commitment among primary school teachers.

\section{Hypotheses-}

On the basis of the previous studies done in this area , following hypotheses were made :

1. Teachers who will be more satisfied with their working conditions will be more competent in classroom teaching.

2. Primary school teachers who will be more satisfied with their working conditions will be more professionally committed.

3. Teachers who will be more professionally committed will be more competent in teaching and other educational activities.

All these hypotheses will be tested in null form

\section{Delimitations-}

In any research despite the best efforts by the researcher it is not possible to include all aspects related to the study. The delimitation of the present study is that the study will be limited to selected primary schools of the city of Lucknow.

\section{Operational Definitions of the key terms- Teaching Competency-}

Teaching competency for the study will mean the competencies of the primary school teachers in performing their expected jobs. This will include competencies like-Management, Planning lessons etc.

Professional Commitment-

Professional Commitment will mean selected teachers motivation and intrinsic urge to perform their job. The faith and value they attach to their profession

\section{Job Satisfaction-}

Job satisfaction will mean the assessment of attitudes possessed by the teachers towards their job which will include aspects like-working conditions, salary etc.

\section{Primary School Teachers-}

Primary School Teachers are those teachers who teach class I - class V

\section{Review of the related literature}

Researcher takes advantage of the knowledge, which has accumulated in the past as a result of constant human endeavor. It can never be undertaken in isolation of the work that has already been proposed by a researcher. A careful review of the research journals, books, dissertation, thesis and other sources of information on the problem to be investigated is one of the important steps in planning of any research study. As indicated in the past chapter, a review of related literature must precede any well planned research study. The review of the literature enables the researcher to define the limits of his field. It helps the researcher to delimit and define his problem. By reviewing the related literature the researcher can avoid purposeless areas. Review of related literature allows the researcher to acquaint himself with current knowledge of the field in which he is going to conduct the research. Best and Kahn(1998), recognizes the importance of this step when they write, " a summary of the writing of the recognized authorities and of previous research provides evidence that the researcher is familiar with what is already known and what is still unknown and untested."

\subsection{Studies done abroad:}

Michalinos and Zembylas,(2006), published a paper in, “ A journal of comparative education,vol.36,no.2,pp229-47 on the sources of teachers job satisfaction and dissatisfaction. The paper aims to contribute to the limited literature on teacher job satisfaction in developing countries. Drawing on interviews with 52 teachers and administrators in 17 schools, the paper describes the sources $\mathrm{f}$ job satisfaction and dissatisfaction of teachers and the impact on how teacher feel. Teachers emphasized their satisfaction with interactions with students, relationships held with colleagues and opportunities to contribute to the growth of individuals and the development of society. Sources of dissatisfaction were social problems and their impact on teacher's work, students lack of interest and bad behavior, the centralized educational system and the back of professional autonomy in schools and teacher education

Butt (2005), attempted to find out the differences in teachers job satisfaction and workload in primary schools. The findings of the study was reported as that internal factors like modernization and remodeling of the work atmosphere will be more relevant than externally imposed measures like government policy. The study also reported that increased workload has reduced the job satisfaction of the primary school teachers. 
In the research conducted by Australian council for educational research in 2005. the research aimed at how the work of a teacher could be better structured, resourced and organized to support more effective classroom teaching. Some of the key findings of the study are:

- Teachers were satisfied with most aspects of their work, they were on average clearly dissatisfied with the amount of non teaching work they were expected to do

- Commitment and dedication of primary teachers were apparently leading many teachers to place unrealistic perfectionist demands on themselves

- Nature of primary teaching involves extensive interactions, both scheduled and unscheduled with a large number of people throughout the day. A factor that became clear in the diaries was that primary teachers had very little, if any properly scheduled "down-time" during the day.

Sargent (2005), in the study, "keeping teachers happy : Job satisfaction among primary school teachers in rural northwest china through a study of teacher job satisfaction in impoverished rural areas in northwest china, the authors examine the factors leading to satisfaction among teachers serving poor rural communities. A survey of rural primary school teachers, principals, and village leaders conducted in the year 2000 in Gansu is analysed.In this article the authors test whether younger and better educated teachers have lower level of satisfaction. In addition the authors report that female teachers, married teachers, teachers who are more highly ranked and those who are more socially similar to their surrounding communities are more satisfied. A study done by Edward,2004, on the perceptions of elementary teachers regarding the relationships between the performance evaluation process and improvement of elementary teacher practices. The study provided a variety of results. A few of the significant results were that teachers in this study view the evaluation process in which they are involved in as a positive process to be one in which improves evaluation process to be one on which improves teaching practice. The teachers believed that if perceptions of the purpose of the evaluation process are for teacher improvement and growth, rather than personnel decisions it will in fact improve teacher practice. Gamoran (2003), in his study " School Effectiveness and school improvement, found that professional development opportunities are more likely to increase teachers sense of professional commitment if they are school wide, while programs in which individuals teachers participate without other teachers from their school are unlikely to do so. One effect of professional development at the school level may be the creation or enhancement of professional community. Professional commitment may strengthen teacher social ties, contributing to the schools social resource. Avila (1979), examined the effects of selected teaching competencies on secondary school students achievement. The purpose was to determine whether specific teaching competencies applied in the classroom would increase students learning. The sample consisted of control and experimental teachers and students in English and social studies classes at the secondary level. The data were analyzed by analysis of covariance. Selected findings of the study were:

1. Through a staff development program teachers can be taught to apply specific teaching competencies in the classroom.

2. Teaching competency properly applied in the classroom will significantly increase the probability that students will learn.

3. Teachers can be trained to properly apply specific teaching competencies and the principles of learning in the classroom.

4. The planned and consistent use of teaching competency can be uniformly effective in increasing the learning at three cognitive levels, knowledge, comprehension and application.

In a study done by Miller and John (1982), on teachers in transition. He studied the effect of aging on the job satisfaction and dissatisfaction of teachers. Discussions by 56 educators from a Canadian school district on their job satisfactions and dissatisfactions, aspirations, and life transitions in tape recorded interviews provided the primary data for this study of adult development among teachers and administrators. Secondary data were obtained from a questionnaire survey of an additional 383 teachers. The respondents were grouped by age according to the adult developmental stages outlined in the works of Daniel Levinson and Gail Sheehy. Teachers under 30 expressed greater dissatisfaction and teachers over 40 expressed greater satisfactions than did other teachers surveyed. Satisfaction derived mainly from work with students, while dissatisfaction resulted from frustration over the attitudes of a few students. Most teachers felt fulfilled in their work. Women were more optimistic than men about promotion and had more diverse aspirations. Male teachers in their early thirties stressed the importance of work while women of the same age found fulfillment in their families. By the time teachers reached their early forties, women found more fulfillment in work and men found more in their families. Teachers older than 45 found fulfillment in both work and family. This report includes illustrative quotes from the interviews and a copy of the questionnaire

\subsection{Studies done in India:}

Bindu and Kumar,(2006) in the study on job satisfaction and stress coping skills of primary school teachers reported job satisfaction expresses the extent of match between teachers expectation of the job, job 
requirements and the satisfaction derived from their jobs. There seems to be a growing discontentment towards teaching as a result of which standards of education are falling. Teachers are dissatisfied despite of different plans and programs which have been implemented to improve their job. The study revealed that job satisfaction differentiates male and female primary school teachers and there is positive correlation between job satisfaction and stress coping skills.

Employment News, vol.28, No.48, pp1-2, dated 28 Feb.' 5 March'2004 Competency development must be a continuous process in the organization .A clear understanding of the process competency development will help the organizations to training effectively.

In a study done Seema Singh (2003), on teaching competency of primary school teachers. The study revealed that teaching competencies includes the acquisition and demonstration of the composite skills required for student teaching like introducing a lesson, fluency in questioning, probing question, explaining, pace of lesson, reinforcement, understanding child psychology, recognizing behavior, classroom management and giving assignment. Desai and Deshpande (1996) examined the interactive effect of sources of feedback and students neurotic personality on student teacher competence. The sample of the study comprised of 50 male B. Ed. trainees. The tools used to collect data were personality inventory, standard progressive matrices, teaching assessment battery and feedback forms of occurrence schedule and rating scales. The collected data were treated with analysis of covariance and ANOVA. The major findings of the study were:

1. There was no significant difference in the teaching competencies of high neurotic and low neurotic student teachers.

2. Neurotic teachers exposed to audio feedback condition differed in their teaching competence when compared to student teachers exposed to supervisory feedback.

3. There was no significant difference in the teaching competence of student teachers receiving audio feedback.

Ramakrishnan (1989), did a study on Job satisfaction of teachers at various levels and found that teachers in general were satisfied with their job. Their job satisfaction was influenced by many criteria but important one came out as employer's attitude and salary giving some importance to working environment.

In a study done by Srivastava(1986), for finding criteria of primary school teachers to have job satisfaction and professional commitment of primary school teachers. Some of the major findings of the study are stated as-

- Female primary school teachers compared to their male counterpart had higher job satisfaction

- Professional commitment was rated more important ad found higher than job satisfaction

- Female teachers were professionally committed more than male teachers of primary schools.

In a paper presented by Singh and Singh, on Developing Competencies through ICT in Teacher Education, discussed that Teacher Education enhances the professional quality of teachers. The need of the hour is to acquaint pre-service and in-service teachers with technological advancements in hardware and software so as to increase the competency of modern teachers. The learner oriented educational and technological developments in the form of e-content, e-books, virtual classrooms and web-based instruction have necessitated the restructuring of the teacher education curriculum This paper focuses on the competencies needed to be developed in pre-service and in-service teachers with the appropriate use of ICT.

\subsection{Overall Position:}

The trend of the studies done on concepts professional development and job satisfaction shows that numerous studies have been done on these topic in the western countries but a little emphasis has been given to such studies in India. Studies have been done to see relation between aging and professional commitment among teachers. Results have shown that with increasing age Commitment of teachers decrease towards the profession. Studies done on job satisfaction are mostly centered towards the organization like corporate offices but none of the studies whether in India or abroad is done on Job Satisfaction among teachers leaving the exceptional which have been done years back like one done by Jha (1986). There have been no recent studies related to this aspect of teaching. Studies have been conducted on Teaching Competencies both in India and abroad but most or we can say nearly all of them are done among secondary school teacher or teachers at higher level of education. None of the studies are done keeping in mine teaching competencies of primary school teachers. Numerous studies have been done in the field of commitment, teaching competency and job satisfaction. However, no studies could be found with regard to professional commitment, job satisfaction and teaching competency among Primary school teachers. Keeping this in mind efforts have been maid to study the professional commitment, job satisfaction and teaching competency among primary school teachers in the city of Lucknow. This study also attempts to find the relationship among all three variables and there influence on each other. 


\subsection{Type of Research:}

\section{Methodology}

Research may be defined as systematic attempt to obtain meaningful answers to the questions about events or situations. Research implies scientific methods and follows a systematic procedure. Methodology constitutes an overview of the layout including the details how the research is to be executed. This includes the blueprint for the collection, measurement and analysis of data. It includes the overall methods of data processing and plan of analysis. The present study is example of Descriptive Research and can be classified under survey method. According to Best and Kahn (1998), "descriptive research, sometimes known as non experimental or co relational research, deals with the relationships between variables, the testing of hypotheses, and the development of generalizations, principles, or theories that have universal validity. It is concerned with functional relationships." Descriptive research tries to answer, 'what is?' in this the researcher does not manipulate the variables or arrange for the events to happen. The survey method is conducted to collect descriptions of the existing phenomena with the intention of utilizing the data to justify the prevalent practices and conditions or to make plan for their improvement. According to best and Kahn (1998), "survey must not be confused with the mere clerical routines of gathering and tabulating figures. It involves a clearly defined problem and definite objectives. It requires expert and imaginative planning, careful analysis and interpretation of the data gathered, and logical and skillful reporting of the findings."

\subsection{Variables:}

Variables are those characteristics or conditions that are controlled, manipulated or observed by the researcher. Best and Kahn (1998) defines independent variable as... "The conditions or characteristics that the experimenter manipulates or controls in his or her attempt to ascertain their relationship to observed phenomena. The dependent variables are the conditions or characteristics that appear, disappear, or change as the experimenter introduces, removes or changes independent variables. The variables in the present study are:

\section{- $\quad$ Teaching Competency \\ - $\quad$ Professional commitment \\ - Job satisfaction}

\section{3 Population}

All teachers both male and female of all Private and government schools of Lucknow city.

\subsection{Sample}

The sample selected for the present study consisted of 100 primary school teachers, from 10 schools $(5$ private and 5 government schools) of Lucknow.

\subsection{Sampling procedure}

The sampling was done in two stages:

1. Selection of Institutions: A list of all the primary schools of the city was obtained from the office of the Director of Education. From this list 10 schools were selected on convenience basis by convenient sampling 2. Selection of Teachers: After the institutions for the study were chosen, the next step was the selection of teachers. The selection of teachers was also done on the basis of convenience by convenient sampling

Table No. 3.1 No. of teachers selected

\begin{tabular}{|c|c|c|}
\hline S.No & $\begin{array}{c}\text { Institutions } \\
\text { government) }\end{array}$ & No.of teacher selected \\
\hline 1. & A & 10 \\
\hline 2. & B & 10 \\
\hline 3. & C & 10 \\
\hline 4. & D & 10 \\
\hline 5. & E & 10 \\
\hline 6. & ( Private) & 10 \\
\hline 7. & F & 10 \\
\hline 8. & G & 10 \\
\hline 9. & H & 10 \\
\hline 10. & I & 10 \\
\hline
\end{tabular}

Total number of primary school teachers $=100$

Teachers from Private schools $=50$

Teachers from government schools $=50$ 
To carry out any meaningful research, data is gathered on the basis of which the hypotheses are tested. Selection or development of appropriate tools for any study depends upon numerous considerations such as the objective of the study, the amount of time at the disposal of the researcher, score and interpret the results etc. Depending on the nature of the problem and the purpose of the study. In the present study three tools have been used:

- Teacher's teaching competency scale - self made

- Teacher's professional commitment scale- ( Maiti, 2005)

- $\quad$ Teacher's job satisfaction scale (TJSS) - Dr. S.P. Gupta and Dr. J. P. Srivastava

\subsubsection{Description of the tools:}

\section{Teacher's Teaching Competency Scale}

This tool was developed by the researcher herself for the purpose of the present study. There was a need to develop this tool as the other tools present for assessing teaching competencies of teachers were either for higher levels of education and did not well suited for the primary level teachers, and some tools like that constructed by B. K. Passi and M. S. Lalita deals with competencies of the teachers in relation to classroom teaching only and do not cover all the related competencies which should be present in a successful teacher. The tool was developed to access the teaching competency of primary school teachers. The tool was based on the ten inter related teaching competencies categories given by NCTE. The categories on which the tool was based are:-

1) Contextual competencies

2) Conceptual competencies

3) Content competencies

4) Transactional competencies

5) Competencies related to educational activities

6) Competencies to develop teaching learning material

7) Evaluation competencies

8) Management competencies

9) Competencies related to working with parents

10.)Competencies related to working with community and other agencies

\section{Preparation of items of the scale:}

Initially, the scale consisted of 56 items. The statements were framed to convey the essential meaning.

- Contextual competencies include not only educational but social and cultural systems also. It includes dealing with problems of wastage and stagnation, diversities in society, developing cohesive society and issues like urbanization and value inculcation

- Conceptual competencies include knowledge about stage of child development, right prespective toward education and implications of education

- Content competencies include joyful activities, media intervention, individual learning and provision of enriched environment for learning

- Transactional competencies include planning of action and evaluation, inclusion of activities like story telling, singing etc in teaching process

- Competencies related to other educational activity includes human values, celebration of national events and community life activities

- Competencies to develop teaching learning material include innovative ways to teaching and local visits to banks and other community resources

- Evaluation competencies include positivistic evaluation process, importance of feedback etc.

- Management competencies include skills of classroom management and role and responsibilities of teacher

- Competencies related to working with parents include role of parents and requirement for their cooperation in teaching learning process

- Competencies related to working with community and other agencies include the knowledge about importance of community in the holistic development of students

Table no. 3.2

Blue print of the constructed tool- Teaching Competency Scale

\begin{tabular}{|l|l|l|l|}
\hline S. No. & Competencies & No. of items in the Initial Draft & Final no. of Items left after Expert's opinion \\
\hline 1. & Contextual & 4 & 4 \\
\hline 2. & Conceptual & 10 & 9 \\
\hline 3. & Content & 10 & 10 \\
\hline 4. & Transactional & 11 & 11 \\
\hline 5. & Related to educational activities & 4 & 4 \\
\hline 6. & Teaching Learning Material & 2 & 1 \\
\hline 7. & Evaluation & 3 & 3 \\
\hline
\end{tabular}




\begin{tabular}{|l|l|l|l|}
\hline 8. & Management & 3 & 3 \\
\hline 9. & Related to working with parents & 5 & 4 \\
\hline 10. & Related to working with community & 4 & 1 \\
\hline \multicolumn{2}{|l}{ Total no. of Items } & 56 & 50 \\
\hline
\end{tabular}

Both negative and positive statements were included in the tool. Five options were given against each item ranging from 'strongly agree' to 'strongly disagree'.

\section{Scoring Pattern}

Table no.3.3

Scoring system for the five alternative responses

\begin{tabular}{|l|l|l|l|l|l|}
\hline Type of statement & Strongly agree & agree & undecided & disagree & Strongly disagree \\
\hline Positive & 5 & 4 & 3 & 2 & 1 \\
\hline Negative & 1 & 2 & 3 & 4 & 5 \\
\hline
\end{tabular}

The total score varies from 50 to 250 showing lowest to highest teaching competencies.

\section{Description of the scale:}

There are 50 items pertaining to ten dimensions in the scale. All the items are positively worded except item numbers 5,7,14,15,17,20,23,26,27,29,34,38,44,48, and 49.the scale is in English.

Teacher's professional commitment scale (TPCS) made by Maiti (2005)

The test was designed to use with teachers working in various institutions at secondary level. This scale is based on five areas of commitment as identified and mentioned by Dave. the five areas are:

- $\quad$ Commitment to learner

- $\quad$ Commitment to the society

- $\quad$ Commitment to the profession

- $\quad$ Commitment to attaining excellence for professional actions

- $\quad$ Commitment to the basic values

There are 50 items pertaining to the five dimensions in the scale. All the items are positively worded except item number 5, 6, 12, 33 and 46. The scale is in English. The distribution of the various items related to the different areas of commitment is given in the following table:

Table no. 3.4

\begin{tabular}{|l|l|l|l|}
\hline S. No. & Areas of commitment & No. of items & Serial No. of items \\
\hline a. & To the learner & 08 & 1 to 8 \\
\hline b. & To the society & 12 & 9 to 20 \\
\hline c. & To the profession & 10 & 21 to 30 \\
\hline d. & To attaining excellence for professional actions & 08 & 31 to 38 \\
\hline e. & To basic values & 12 & 39 to 50 \\
\hline & Total & $\mathbf{5 0}$ & \\
\hline
\end{tabular}

Table No. 3.5

Scoring system for the five alternative responses

\begin{tabular}{|l|l|l|l|l|l|}
\hline Type of statement & Strongly agree & agree & undecided & disagree & Strongly disagree \\
\hline Positive & 5 & 4 & 3 & 2 & 1 \\
\hline Negative & 1 & 2 & 3 & 4 & 5 \\
\hline
\end{tabular}

Teachers job satisfaction scale (TJSS): Author of the test- Dr. S.P.Gupta and Dr. J.P. Srivastava

The scale was designed to use with the teachers from primary schools, secondary schools, degree and post graduate. This scale is based on twenty aspects related to job satisfaction. The 20 aspects included are as follows:

$\begin{array}{ll}\text { - } & \text { Salary and fringe benefits } \\ \text { - } & \text { Interrelations relations among colleagues } \\ \text { - } & \text { Teacher principal relations } \\ \text { - } & \text { Profession } \\ \text { - } & \text { Institution } \\ \text { - } & \text { Working conditions } \\ \text { - } & \text { Work load } \\ \text { - } & \text { Ability utilization } \\ \text { - } & \text { Achievement }\end{array}$




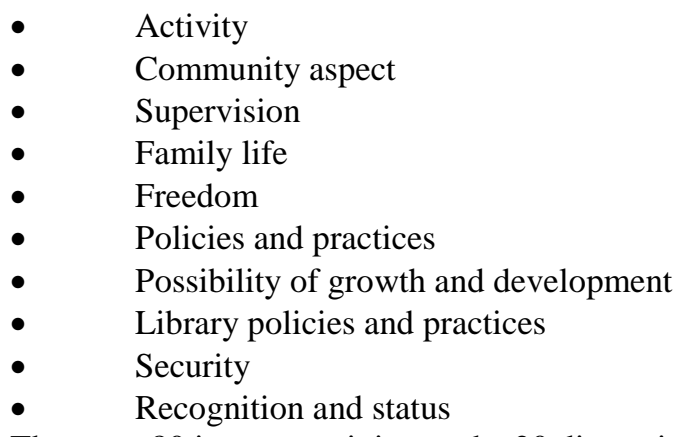

There are 80 items pertaining to the 20 dimensions in the scale. Each dimension consists of four items. All the items except $3.28,32,39,44,45,46,48,53,54,70,77,78$ and 80 are positively worded. TJSS is a self administrating instrument. The subject's are supposed to tick mark the option which they find most appropriate. There is no time limit to answer the scale. Scoring: the scoring system is based on a five point likert type scale with the following response alternatives.

Table No. 3.6

Scoring system for the five alternative responses

\begin{tabular}{|l|l|l|l|l|l|}
\hline Type of statement & Strongly agree & agree & undecided & disagree & Strongly disagree \\
\hline Positive & 5 & 4 & 3 & 2 & 1 \\
\hline Negative & 1 & 2 & 3 & 4 & 5 \\
\hline
\end{tabular}

\subsection{Procedure:}

Data Collection

The investigator personally went to all the selected institutions from where the data was to be collected. First of all permission was sought from the head of the institution and the information about the number of primary teachers and their availability was found.The list of all the teachers was taken and then ten teachers were selected for the purpose of data collection. Initially rapport was formed with the teachers and the purpose of the study was explained to them. Some instructions were given to the teachers orally and then questionnaires were given to the selected teachers. The teachers asked the researcher to collect the forms next day. The forms were collected and were checked on the spot whether they are completely filled or not. Researcher thanked the teachers for taking out their precious time and cooperating in the process of research.

Analysis of data

Scoring: After collecting the response sheets back from the teachers the scoring was done as mentioned for TJSS, TPCS and for teaching competency scale as decided by the researcher.

Statistical techniques employed: The scores of all the teachers were tabulated separately, after which Pearson's Moment Correlation and t- test was used.

The general purpose of Pearson's Moment Correlation is to derive if any relationship between variables taken in the study and the t- values is used to observe the influence of different levels of job satisfaction on teaching competency and professional commitment.

\section{Analysis of Data, Results and Interpretation}

Collection, organization and analysis of data is an important step in any research activity as it helps a researcher to develop an understanding about the variables, concepts, find and reveal any inherent relationship that may exist between them. The results obtained from such an analysis are to be interpreted in terms of objectives of the study to reach conclusions about the population under study. The main purpose of analyzing the data is to summarize the observations so that they yield answers to research problem. Thus, an important step of research involves study of a sample statistics to make predictions about the representative population.

4.1 Variables: The variables in the present study are-

- Teaching competency

- Job satisfaction

- $\quad$ Professional commitment

The analysis of data and the results have been discussed under three sections in relation to the objectives of the study. The level of significance used during analysis of data is 0.05 .

4.1.1 Section 1-This section studies the influence of job satisfaction on teaching competency and its ten dimensions.

Objective 1.0: To find relation ship between job satisfaction and teaching competency 
Hypothesis1.0: Teachers who will be more satisfied with their job will be more competent in teaching.

Table 4.1.0

Relationship between Teaching competency \& Job satisfaction

\begin{tabular}{|ll|l|l|}
\hline Variables & Value of ' $r$ ' & Result \\
\hline$\bullet$ & $\begin{array}{l}\text { Teaching competency } \\
\text { Job satisfaction }\end{array}$ & $\mathbf{0 . 0 3 4}$ & Not significant \\
\hline & & \\
\hline
\end{tabular}

The value of $r$ that is 0.034 is not significant at .05 level of significance. The value shows very less positive correlation between teaching competency and job satisfaction. Thus we reject the hypothesis that there is relationship between teaching competency and job satisfaction.

Objective 1.1: To find relation ship between job satisfaction and transactional teaching competency

Hypothesis 1.1: Teachers who will be more satisfied with their job will be more competent in transactional aspect of teaching

Table 4.1.1

Relationship between Transactional teaching competency \& Job satisfaction

\begin{tabular}{|ll|l|l|}
\hline Variables & Value of ' $r$ ' & Result \\
\hline$\bullet$ & $\begin{array}{l}\text { Transactional teaching competency } \\
\text { Job satisfaction }\end{array}$ & $\mathbf{0 . 1 3 5}$ & Not significant \\
\hline
\end{tabular}

The value of $r$ that is 0.135 is not significant at .05 level of significance. The value shows very less positive correlation between transactional teaching competency and job satisfaction. Thus we reject the hypothesis that there is relationship between transactional teaching competency and job satisfaction.

Objective 1.2: To find relation ship between job satisfaction and contextual teaching competency

Hypothesis 1.2: Teachers who will be more satisfied with their job will be more competent in contextual aspect of teaching.

Table 4.1.2

Relationship between contextual teaching competency $\&$ job satisfaction

\begin{tabular}{|ll|l|l|}
\hline Variables & Value of ' $r$ ' & Result \\
\hline$\bullet$ & $\begin{array}{l}\text { Contextual teaching competency } \\
\text { Job satisfaction }\end{array}$ & $\mathbf{0 . 1 0 5}$ & Not significant \\
\hline
\end{tabular}

The value of $r$ that is 0.105 is not significant at .05 level of significance. The value shows very less positive correlation between contextual teaching competency and job satisfaction. Thus we reject the hypothesis that there is relationship between contextual teaching competency and job satisfaction.

Objective 1.3: To find relation ship between job satisfaction and conceptual teaching competency

Hypothesis 1.3: Teachers who will be more satisfied with their job will be more competent in conceptual aspect of teaching

Table 4.1.3

Relationship between Conceptual teaching competency \&job satisfaction

\begin{tabular}{|ll|l|l|}
\hline Variables & Value of ' $r$ ' & Result \\
\hline$\bullet$ & $\begin{array}{l}\text { Conceptual teaching competency } \\
\text { Job satisfaction }\end{array}$ & $\mathbf{0 . 0 1 5}$ & Not significant \\
\hline
\end{tabular}

The value of $r$ that is 0.015 is not significant at .05 level of significance. The value shows very less positive correlation between conceptual teaching competency and job satisfaction. Thus we reject the hypothesis that there is relationship between conceptual teaching competency and job satisfaction.

Objective 1.4: To find relation ship between job satisfaction and Evaluation competency

Hypothesis 1.4: Teachers who will be more satisfied with their job will be more competent in evaluation.

Table 4.1.4

Relationship between Evaluation competency \&Job satisfaction

\begin{tabular}{|ll|l|l|}
\hline Variables & Value of ' $r$ ' & Result \\
\hline$\bullet$ & $\begin{array}{l}\text { Evaluation competency } \\
\text { Job satisfaction }\end{array}$ & $\mathbf{0 . 0 0 3}$ & Not significant \\
\hline
\end{tabular}

The value of $r$ that is 0.003 is not significant at .05 level of significance. The value shows very less positive correlation between evaluation competency and job satisfaction. Thus we reject the hypothesis that there is relationship between evaluation competency and job satisfaction.

Objective 1.5: To find relation ship between job satisfaction and teaching competency related to other educational activities 
Hypothesis 1.5: Teachers who will be more satisfied with their job will be more competent in other educational activities related to teaching.

Table 4.1.5

Relationship between teaching competency related to other educational activities \& Job satisfaction

\begin{tabular}{|l|l|l|}
\hline Variables & Value of ' r' & Result \\
\hline$\bullet \quad \begin{array}{l}\text { teaching competency related to other educational activities } \\
\text { Job satisfaction }\end{array}$ & $\mathbf{0 . 0 2 4}$ & Not significant \\
\hline
\end{tabular}

The value of $r$ that is 0.024 is not significant at .05 level of significance. The value shows very less positive correlation between teaching competency related to other educational activities and job satisfaction. Thus we reject the hypothesis that there is relationship between teaching competency related to other educational activities and job satisfaction. Objective 1.6: To find relation ship between job satisfaction and Management competency

Hypothesis 1.6: Teachers who will be more satisfied with their job will be more competent in Managerial aspect of teaching.

Table 4.1.6

Relationship between Management competency \& Job satisfaction

\begin{tabular}{|ll|l|l|}
\hline Variables & Value of ' $r$ ' & Result \\
\hline$\bullet$ & $\begin{array}{l}\text { Management competency } \\
\text { Job satisfaction }\end{array}$ & $\mathbf{- 0 . 1 5 0}$ & Not significant \\
\hline
\end{tabular}

The value of $r$ that is -0.150 is not significant at .05 level of significance. The value shows very less negative correlation between management competency and job satisfaction. Thus we reject the hypothesis that there is relationship between management competency and job satisfaction.

Objective 1.7: To find relation ship between job satisfaction and competencies related to working with parents. Hypothesis 1.7: Teachers who will be more satisfied with their job will be more competent in working with parents.

Table 4.1.7

Relationship between Competencies related to working with parents and Job satisfaction

\begin{tabular}{|ll|l|l|}
\hline Variables & Value of ' $r$ ' & Result \\
\hline$\bullet$ & $\begin{array}{l}\text { Competencies related to working with parents } \\
\text { Job satisfaction }\end{array}$ & 0.044 & Not significant \\
\hline
\end{tabular}

The value of $r$ that is 0.044 is not significant at .05 level of significance. The value shows very less positive correlation between competencies related to working with parents and job satisfaction. Thus we reject the hypothesis that there is relationship between competencies related to working with parents and job satisfaction.

Objective 1.8: To find relation ship between job satisfaction and content competency

Hypothesis1.8: Teachers who will be more satisfied with their job will be more competent in working on content of teaching

Table 4.1.8

Relationship between Content competency \& Job satisfaction

\begin{tabular}{|ll|l|l|}
\hline Variables & Value of ' $r$ ' & Result \\
\hline$\bullet$ & $\begin{array}{l}\text { Content competency } \\
\text { Job satisfaction }\end{array}$ & $\mathbf{- 0 . 2 3 5}$ & Not significant \\
\hline
\end{tabular}

The value of $r$ that is -0.235 is not significant at .05 level of significance. The value shows very less negative correlation between content competency and job satisfaction. Thus we reject the hypothesis that there is relationship between content competency and job satisfaction.

Objective1.9: To find relation ship between job satisfaction and competencies related to preparation of teaching learning material.

Hypothesis1.9: Teachers who will be more satisfied with their job will be more competent in preparation of teaching learning material. 
Table 4.1.9

Relationship between Competencies related to preparation of teaching learning material \& Job satisfaction

\begin{tabular}{|ll|l|l|}
\hline Variables & Value of ' $r$ ' & Result \\
\hline$\bullet$ & $\begin{array}{l}\text { Competencies related to preparation of teaching learning material } \\
\text { Job satisfaction }\end{array}$ & $\mathbf{- 0 . 2 3 5}$ & Not significant \\
\hline
\end{tabular}

The value of $r$ that is -0.235 is not significant at .05 level of significance. The value shows very less negative correlation between competencies related to preparation of teaching learning material and job satisfaction. Thus we reject the hypothesis that there is relationship between competencies related to preparation of teaching learning material and job satisfaction.

Objective 1.10: To find relation ship between job satisfaction and competencies related to work with community.

Hypothesis1.10: Teachers who will be more satisfied with their job will be more competent in working with community.

Table 4.1.10

Relationship between Competencies related to work with community and Job satisfaction

\begin{tabular}{|ll|l|l|}
\hline Variables & Value of ' $r$ ' & Result \\
\hline$\bullet$ & $\begin{array}{l}\text { Competencies related to work with communtiy } \\
\text { Job satisfaction }\end{array}$ & $\mathbf{- 0 . 0 6 2}$ & Not significant \\
\hline
\end{tabular}

The value of $r$ that is -0.062 is not significant at .05 level of significance. The value shows very less negative correlation between competencies related to work with community and job satisfaction. Thus we reject the hypothesis that there is relationship between job satisfaction and competencies related to work with community A teacher being competent in her or his teaching does not totally depend on her or his job satisfaction level. The analysis of the collected data shows no significant relationship between teaching competencies and job satisfaction levels of the primary school teacher

Table 4.1.11

Relationship between Job satisfaction and Teaching Competency

\begin{tabular}{|c|c|c|c|c|}
\hline \multicolumn{2}{|l|}{ Variables } & \multirow{2}{*}{$\begin{array}{l}\text { Correlation } \\
0.034\end{array}$} & \multirow{2}{*}{$\begin{array}{l}\text { Interpretation } \\
\text { Very low positive } \\
\text { correlation }\end{array}$} & \multirow{2}{*}{$\begin{array}{l}\text { Significance } \\
\text { Not } \\
\text { Significant }\end{array}$} \\
\hline $\begin{array}{l}\text { Job } \\
\text { Satisfaction }\end{array}$ & Teaching Competency & & & \\
\hline & Contextual Competency & 0.105 & $\begin{array}{l}\text { Very low positive } \\
\text { correlation }\end{array}$ & $\begin{array}{l}\text { Not } \\
\text { Significant }\end{array}$ \\
\hline & Evaluation Competency & 0.003 & $\begin{array}{l}\text { Very low positive } \\
\text { correlation }\end{array}$ & $\begin{array}{l}\text { Not } \\
\text { Significant }\end{array}$ \\
\hline & Competency related to other educational activities & 0.024 & $\begin{array}{l}\text { Very low positive } \\
\text { correlation }\end{array}$ & $\begin{array}{l}\text { Not } \\
\text { Significant }\end{array}$ \\
\hline & Management Competency & -0.150 & negative correlation & $\begin{array}{l}\text { Not } \\
\text { Significant }\end{array}$ \\
\hline & $\begin{array}{l}\text { Competency related to preparation of teaching } \\
\text { learning material }\end{array}$ & 0.112 & $\begin{array}{l}\text { Very low positive } \\
\text { correlation }\end{array}$ & $\begin{array}{l}\text { Not } \\
\text { Significant }\end{array}$ \\
\hline & Competency related to working with community & -0.062 & negative correlation & $\begin{array}{l}\text { Not } \\
\text { Significant }\end{array}$ \\
\hline
\end{tabular}

Section 2-This section studies the influence of job satisfaction on professional commitment and its five dimensions.

Objective 2.0 : to find relationship between job satisfaction and professional commitment among primary school teachers.

Hypothesis 2.0: primary school teachers who will be more satisfied with their working conditions will be more committed to profession. 
Table 4.2.0

Relationship between Commitment to profession \& Job satisfaction

\begin{tabular}{|c|c|c|}
\hline Variables & Value of ' $r$ ' & Result \\
\hline $\begin{array}{ll}- & \text { Commitment to profession } \\
\text { Job satisfaction }\end{array}$ & 0.248 & Significant \\
\hline
\end{tabular}

The value of $r$ that is 0.248 is significant at 0.05 level of significance. the value shows very high positive correlation between commitment to profession and job satisfaction level of primary school teachers. Thus we accept the hypothesis that there is relation between commitment to profession and job satisfaction level of primary school teachers

Objective 2.1 : to find relationship between job satisfaction and commitment to learners among primary school teachers.

Hypothesis 2.1: primary school teachers who will be more satisfied with their working conditions will be more commited to their learners.

Table 4.2.1

Realtionship between Commitment to learner \& Job satisfaction

\begin{tabular}{|ll|l|l|}
\hline Variables & Value of ' $r$ ' & Result \\
\hline$\bullet$ & $\begin{array}{l}\text { Commitment to learner } \\
\text { Job satisfaction }\end{array}$ & $\mathbf{0 . 0 8 4}$ & Not significant \\
\hline
\end{tabular}

The value of $r$ that is 0.084 is not significant at 0.05 level of significance. the value shows very less positive correlation between commitment to learner and job satisfaction level of primary school teachers. Thus we reject the hypothesis that there is relation between commitment to learner and job satisfaction level of primary school teachers.

Objective 2.2 : to find relationship between job satisfaction and commitment to society among primary school teachers.

Hypothesis 2.2: primary school teachers who will be more satisfied with their working conditions will be more committed to the society.

Table 4.2.2

Relationship between Commitment to society \& Job satisfaction

\begin{tabular}{|ll|l|l|}
\hline Variables & Value of ' $r$ ' & Result \\
\hline$\bullet$ & $\begin{array}{l}\text { Commitment to society } \\
\text { Job satisfaction }\end{array}$ & $\mathbf{0 . 1 6 0}$ & Not significant \\
\hline
\end{tabular}

The value of $r$ that is 0.160 is not significant at 0.05 level of significance. the value shows very less positive correlation between commitment to society and job satisfaction level of primary school teachers. Thus we reject the hypothesis that there is relation between commitment to society and job satisfaction level of primary school teachers.

Objective 2.3: to find relationship between job satisfaction and commitment to profession among primary school teachers.

Hypothesis 2.3: primary school teachers who will be more satisfied with their working conditions will be more commited to their profession.

Table 4.2.3

Relationship between Commitment to profession \& Job satisfaction

\begin{tabular}{|ll|l|l|}
\hline Variables & Value of ' $r$ ' & Result \\
\hline$\bullet$ & $\begin{array}{l}\text { Commitment to profession } \\
\text { Job satisfaction }\end{array}$ & $\mathbf{0 . 0 8 4}$ & Not significant \\
\hline
\end{tabular}

The value of $r$ that is 0.084 is not significant at 0.05 level of significance. the value shows very less positive correlation between commitment to profesion and job satisfaction level of primary school teachers. Thus we reject the hypothesis that there is relation between commitment to profession and job satisfaction level of primary school teachers.

Objective 2.4 : to find relationship between job satisfaction and commitment to attaining excellence for professional actions among primary school teachers.

Hypothesis 2.4: primary school teachers who will be more satisfied with their working conditions will be more commited to attaining excellence for professional actions.

Table 4.2.4

Relationship between Commitment to attaining excellence for professional actions \& Job satisfaction

\begin{tabular}{|ll|l|l|}
\hline Variables & Value of ' $r$ ' & Result \\
\hline$\bullet$ & $\begin{array}{l}\text { Commitment to attaining excellence for professional actions } \\
\text { Job satisfaction }\end{array}$ & $\mathbf{0 . 3 3 1}$ & Significant \\
\hline
\end{tabular}


The value of $r$ that is 0.331 is significant at 0.05 level of significance. the value shows very high positive correlation between commitment to attaining excellence for professional actions and job satisfaction level of primary school teachers. Thus we accept the hypothesis that there is relation between commitment to attaining excellence for professional actions and job satisfaction level of primary school teachers.

Objective 2.5: to find relationship between job satisfaction and commitment to basic values among primary school teachers.

Hypothesis 2.5: primary school teachers who will be more satisfied with their working conditions will be more commited to basic values.

Table 4.2.5

Relatioship between Commitment to basic values \& Job satisfaction

\begin{tabular}{|ll|l|l|}
\hline Variables & Value of 'r' & Result \\
\hline$\bullet$ & $\begin{array}{l}\text { Commitment to basic values } \\
\text { Job satisfaction }\end{array}$ & $\mathbf{0 . 2 5 9}$ & Significant \\
\hline
\end{tabular}

The value of $r$ that is 0.259 is significant at 0.05 level of significance. the value shows very high positive correlation between commitment to basic values and job satisfaction level of primary school teachers. Thus we accept the hypothesis that there is relation between commitment to basic values and job satisfaction level of primary school teachers.

Teachers who are satisfied with their job are more committed to their profession. The analysis of the collected data shows there is no significant relation between job satisfaction and some of the dimensions of commitment to profession.

Table 4.3.6

Relationship between Job Satisfaction and Professional Commitment

\begin{tabular}{|l|l|l|l|l|}
\hline \multicolumn{1}{|l|}{$\begin{array}{l}\text { Vob } \\
\text { Satisfaction }\end{array}$} & Professional Commitment(total) & Correlation & Interpretation & Significance \\
\hline & Commitment to learner & 0.248 & $\begin{array}{l}\text { High positive } \\
\text { correlation }\end{array}$ & Significant \\
& Commitment to society & 0.084 & $\begin{array}{l}\text { Very low positive } \\
\text { correlation }\end{array}$ & $\begin{array}{l}\text { Not } \\
\text { significant }\end{array}$ \\
\hline & Commitment to profession & 0.160 & $\begin{array}{l}\text { Very low positive } \\
\text { correlation }\end{array}$ & $\begin{array}{l}\text { Not } \\
\text { significant }\end{array}$ \\
\hline & Commitment to attaining excellence for professional actions & 0.331 & $\begin{array}{l}\text { Very low positive } \\
\text { correlation }\end{array}$ & $\begin{array}{l}\text { Not High positive } \\
\text { significant } \\
\text { correlation }\end{array}$ \\
\hline & Commitment to basic values & 0.259 & $\begin{array}{l}\text { High positive } \\
\text { correlation }\end{array}$ \\
\hline
\end{tabular}

Section 3-This section studies the influence of professional commitment on teaching competency.

Objective 3.0: To find relationship between teaching competency and professional commitment among primary school teachers.

Hypothesis 3.0: Teachers who will be more professionally committed will be more competent in teaching and other educational activities.

Table 4.3.0

Relationship between teaching competency and professional commitment

\begin{tabular}{|ll|l|l|}
\hline Variables & Value of ' $r$ ' & Result \\
\hline$\bullet$ & $\begin{array}{l}\text { Professional commitment } \\
\text { Teaching competency }\end{array}$ & $\mathbf{0 . 1 0 3}$ & Not significant \\
\hline
\end{tabular}

The value of ' $r$ ' that is 0.103 is not significant at 0.05 level of significance. The value shows very les positive correlation between professional commitment and teaching competency. Thus we reject the hypothesis that there is relationship any relation between professional commitment and teaching competency.Teachers who are committed may not equally be competent in the field of teaching as it also depends on the training. The analysis of the data shows no significant relation between professional commitment and teaching competency.

Section 4- This section studies the three levels of job satisfaction - high, average and low and there influence on professional commitment and teaching competency. 
Table 4.4.0

Realtionship between teaching competency and high \& average level of job satisfaction

\begin{tabular}{|l|l|l|l|l|l|l|}
\hline $\begin{array}{l}\text { Teaching } \\
\text { Competency }\end{array}$ & $\begin{array}{l}\text { Mean } \\
\text { Grp.1 }\end{array}$ & $\begin{array}{l}\text { Mean } \\
\text { Grp.2 }\end{array}$ & $\begin{array}{l}\text { Std. } \\
\text { Grp.1 }\end{array}$ & $\begin{array}{l}\text { Std.Dev. } \\
\text { Grp.2 }\end{array}$ & T - value & Result \\
\hline 1 & 45.23 & 44.33 & 5.66 & 5.90 & 0.61 & Not Significant \\
\hline 2 & 41.05 & 40.98 & 6.18 & 5.01 & 0.05 & Not significant \\
\hline 4 & 35.86 & 35.08 & 4.96 & 4.28 & 0.69 & Not significant \\
\hline 5 & 11.50 & 11.31 & 1.79 & 2.02 & 0.39 & Not Significant \\
\hline 6 & 16.18 & 17.33 & 3.33 & 2.73 & -1.54 & Not Significant \\
\hline 7 & 11.50 & 11.31 & 1.63 & 2.23 & 0.37 & Not Significant \\
\hline 8 & 17.73 & 17.19 & 2.10 & 2.60 & 0.85 & Not Significant \\
\hline 9 & 16.95 & 15.31 & 2.40 & 2.80 & 2.40 & Significant \\
\hline 10 & & & & & 1.56 & Not Significant \\
\hline Total & 4.18 & 3.67 & 1.26 & 1.29 & -0.32 & Not Significant \\
\hline
\end{tabular}

The value of $t$ is significant for Management Teaching Competency at 0.05 level of significance and it is not significant for all other teaching competencies at 0.05 level of significance thus we can say that there is significant difference in Management competencies of teachers having high and average job satisfaction. The result shows no significant difference between teaching competency and high and average level of job satisfaction level attained by the teachers.

Table 4.4.1

Relationship between professional commitment and high \& average level of job satisfaction

\begin{tabular}{|l|l|l|l|l|l|l|}
\hline $\begin{array}{l}\text { Professional } \\
\text { commitment }\end{array}$ & $\begin{array}{l}\text { Mean } \\
\text { Grp 1 }\end{array}$ & $\begin{array}{l}\text { Mean } \\
\text { Grp.2 }\end{array}$ & $\begin{array}{l}\text { Std.Dev. } \\
\text { Grp.1 }\end{array}$ & $\begin{array}{l}\text { Std.Dev. } \\
\text { Grp.2 }\end{array}$ & T value & Result \\
\hline 1. & 34.41 & 34.44 & 3.14 & 3.27 & -0.04 & Not significant \\
\hline 2 & 49.68 & 51.90 & 5.49 & 7.23 & -1.29 & Not Significant \\
\hline 3 & 41.36 & 41.94 & 4.57 & 4.62 & -0.49 & Not Significant \\
\hline 4 & 33.82 & 35.94 & 5.02 & 2.51 & -2.43 & Not Significant \\
\hline 5 & 51.32 & 52.40 & 4.14 & 4.90 & -0.91 & Not Significant \\
\hline Total & 214.91 & 221.17 & 17.58 & 15.45 & -1.53 & Not Significant \\
\hline
\end{tabular}

The $t$ value is not significant at 0.05 level of significance thus it can be said that there is no significant difference in professional commitment level of teachers who have high and average levels of job satisfaction.

Table 4.4.2

Relationship between teaching competency and high $\&$ low levels of job satisfaction

\begin{tabular}{|l|l|l|l|l|l|l|}
\hline Teaching Competency & $\begin{array}{l}\text { Mean } \\
\text { Grp. 1 }\end{array}$ & $\begin{array}{l}\text { Mean } \\
\text { Grp.3 }\end{array}$ & $\begin{array}{l}\text { Std.Dev. } \\
\text { Grp.1 }\end{array}$ & $\begin{array}{l}\text { Std. Dev. } \\
\text { Grp.2 }\end{array}$ & T value & Result \\
\hline 1 & 45.23 & 47.50 & 5.66 & 3.79 & -1.66 & Not Significant \\
\hline 2 & 41.05 & 43.12 & 6.18 & 3.59 & -1.45 & Not Significant \\
\hline 3 & 35.86 & 36.15 & 4.96 & 4.19 & -0.22 & Not Significant \\
\hline 4 & 11.50 & 11.15 & 1.79 & 1.93 & 0.64 & Not Significant \\
\hline 5 & 16.18 & 16.96 & 3.33 & 2.46 & -0.93 & Not Significant \\
\hline 6 & 11.50 & 11.00 & 1.63 & 1.98 & -0.94 & Not Significant \\
\hline 7 & 17.73 & 18.04 & 2.10 & 1.80 & -0.55 & Not Significant \\
\hline 8 & 16.95 & 15.38 & 2.40 & 2.52 & 2.20 & Significant \\
\hline 9 & 4.18 & 4.35 & 1.26 & 0.89 & -0.53 & Not Significant \\
\hline 10 & 3.82 & 3.65 & 1.62 & 1.50 & 0.36 & Not Significant \\
\hline Total & 204.00 & 207.31 & 19.57 & 13.77 & -0.69 & Not Significant \\
\hline
\end{tabular}

The value of $\mathrm{t}$ is significant for Management Teaching Competency at 0.05 level of significance and it is not significant for all other teaching competencies at 0.05 level of significance thus we can say that there is significant difference in Management competencies of teachers having high and low job satisfaction. The result shows no significant difference between teaching competency and high and low level of job satisfaction level attained by the teachers. 
Table 4.4.3

Relationship between professional commitment and high \& low levels of job satisfaction

\begin{tabular}{|l|l|l|l|l|l|l|}
\hline Professional Commitment & $\begin{array}{l}\text { Mean } \\
\text { Grp.1 }\end{array}$ & $\begin{array}{l}\text { Mean } \\
\text { Grp.3 }\end{array}$ & $\begin{array}{l}\text { Std.Dev. } \\
\text { Grp.1 }\end{array}$ & $\begin{array}{l}\text { Std.Dev. } \\
\text { Grp.2 }\end{array}$ & t-value & Result \\
\hline 1 & 34.41 & 34.96 & 3.14 & 2.75 & -0.65 & Not Significant \\
\hline 2 & 49.68 & 52.23 & 5.49 & 4.98 & -1.69 & Not Significant \\
\hline 3 & 41.36 & 41.38 & 4.57 & 4.17 & -0.02 & Not Significant \\
\hline 4 & 33.82 & 36.77 & 5.02 & 2.69 & -2.59 & Not Significant \\
\hline 5 & 51.32 & 55.12 & 4.14 & 4.07 & -3.19 & Not Significant \\
\hline Total & 214.91 & 224.85 & 17.58 & 14.56 & -2.14 & Not Significant \\
\hline
\end{tabular}

The $t$ value is not significant at 0.05 level of significance thus the result shows no significant difference between high and low job satisfaction levels and professional commitment.

Table 4.4.4.

Relationship between teaching competency and average $\&$ low levels of job satisfaction

\begin{tabular}{|l|l|l|l|l|l|l|}
\hline Teaching Competency & $\begin{array}{l}\text { Mean } \\
\text { Grp.2 }\end{array}$ & $\begin{array}{l}\text { Mean } \\
\text { Grp.3 }\end{array}$ & $\begin{array}{l}\text { Std.Dev. } \\
\text { Grp.2 }\end{array}$ & $\begin{array}{l}\text { Std.Dev } \\
\text { Grp.3 }\end{array}$ & t-value & Result \\
\hline 1 & 44.33 & 47.50 & 5.90 & 3.79 & -2.44 & Not Significant \\
\hline 2 & 40.98 & 43.12 & 5.01 & 3.59 & -1.94 & Not Significant \\
\hline 3 & 35.08 & 36.15 & 4.28 & 4.19 & -1.05 & Not Significant \\
\hline 4 & 11.31 & 11.15 & 2.02 & 1.93 & 0.32 & Not Significant \\
\hline 5 & 17.33 & 16.96 & 2.73 & 2.46 & 0.58 & Not Significant \\
\hline 6 & 11.31 & 11.00 & 2.23 & 1.98 & 0.60 & Not Significant \\
\hline 7 & 17.19 & 18.04 & 2.60 & 1.80 & -1.49 & Not Significant \\
\hline 8 & 15.31 & 15.38 & 2.80 & 2.52 & -0.12 & Not Significant \\
\hline 9 & 3.67 & 4.35 & 1.29 & 0.89 & -2.38 & Not Significant \\
\hline 10 & 3.94 & 3.65 & 1.51 & 1.50 & 0.80 & Not Significant \\
\hline Total & 200.44 & 207.31 & 18.66 & 13.77 & -1.66 & Not Significant \\
\hline
\end{tabular}

The value of $t$ is not significant at 0.05 level of significance thus it shows that there is no significant difference between average and low job satisfaction levels and teaching competency.

Table 4.4.5

Relationship between professional commitment and average \& low levels of job satisfaction

\begin{tabular}{|l|l|l|l|l|l|l|}
\hline $\begin{array}{l}\text { Professional } \\
\text { Commitment }\end{array}$ & $\begin{array}{l}\text { Mean } \\
\text { Grp.2 }\end{array}$ & $\begin{array}{l}\text { Mean } \\
\text { Grp.3 }\end{array}$ & $\begin{array}{l}\text { Std.Dev } \\
\text { Grp.2 }\end{array}$ & $\begin{array}{l}\text { Std.Dev } \\
\text { Grp.3 }\end{array}$ & t-value & Result \\
\hline 1 & 34.44 & 34.96 & 3.27 & 2.75 & -0.69 & Not Significant \\
\hline 2 & 51.90 & 52.23 & 7.23 & 4.98 & -0.21 & Not Significant \\
\hline 3 & 41.94 & 41.38 & 4.62 & 4.17 & 0.52 & Not Significant \\
\hline 4 & 35.94 & 36.77 & 2.51 & 2.69 & -1.34 & Not Significant \\
\hline 5 & 52.40 & 55.12 & 4.90 & 4.07 & -2.43 & Not Significant \\
\hline Total & 221.17 & 224.85 & 15.45 & 14.56 & -1.01 & Not Significant \\
\hline
\end{tabular}

The $t$ value is not significant at 0.05 level of significance thus the result shows no significant difference between average and low job satisfaction levels and professional commitment.

\subsection{Discussion}

A teacher has a very respectable position in todays society. Teacher is a source of morality and ideals and one who acts as role model in front of whole nation. Being a teacher is to be a change agent transforming ideas into ideals and ideals into institutions which may spread the light of knowledge and wisdom into eternity. A competent and committed teacher $\mathrm{s}$ in demand for today's revolutionary era. Teacher commitment has been identified as one of the most crucial factor for the success of the education and schools. Teacher's commitment is closely associated with their work performance. A competent teacher is able to look into the future of the aspiring student and thus provide his or her best to bring nations dream come true. Teachers who are committed and competent need conducive work environment to prove their abilities and capabilities. In the present study an attempt was made by the researcher to study professional commitment, teaching competency and job satisfaction-their relationship and influence on each other. After employing product moment correlation and ttest analysis the results were as follows:

1. The result showed very high positive correlation between commitment to profession and job satisfaction level of primary school teachers.

2. The result shows very low positive correlation between teaching competency and job satisfaction.

3. The result shows very low positive correlation between professional commitment and teaching competency. 
4. There is no significant difference between teaching competencies level of teachers with high and average levels of job satisfaction.

5. The t-value shows no significant difference between professional commitment level of teachers with high and average levels of job satisfaction.

6. There is no significant difference between teaching competencies level of teachers with high and low levels of job satisfaction.

7. The t-value shows no significant difference between professional commitments levels of teachers with high and low levels of job satisfaction.

8. the result shows no significant difference between teaching competencies level of teachers with average and low levels of job satisfaction

9. The t-value shows no significant difference between professional commitment level of teachers with average and low levels of job satisfaction

\section{Teaching Competency and Job Satisfaction:}

Product moment correlation value of teaching competency and job satisfaction is very low positive. Transactional teaching competency includes planning of action and evaluation, inclusion of activities story telling, singing etc.in teaching process. Transactional teaching competency is very low positively correlated with job satisfaction. Competency of teachers depends on their training and creative bent of mind.Contextual teaching competency includes not only educational but social and cultural system also. It is very low positively correlated to job satisfaction. Conceptual teaching competency includes knowledge about stages of child development, right perspective toward education and implications of education. . It is very low positively correlated to job satisfaction. Content competency includes joyful activities, media intervention, individual learning and provision of enriched environment for learning. It is negatively correlated with job satisfaction. Competencies related to other educational activity include innovative ways of teaching. It is very low positively correlated to job satisfaction. Competencies related to develop teaching learning material is negatively correlated to job satisfaction. Evaluation Competencies include positivistic evaluation process, importance of feedback etc. It is very low positively correlated to job satisfaction. Management Competencies include skills of classroom management and role and responsibilities of teacher. It is negatively correlated to job satisfaction. Competencies related to working with parents include role of parents and requirement of their cooperation in teaching learning process. It is very low positively correlated to job satisfaction. Competencies related to working with community and other agencies include the knowledge about importance of community in the holistic development of students. It is negatively correlated to job satisfaction. A teacher being competent in her or his teaching does not totally depend on his or her job satisfaction level. The analysis of the collected data shows no significant relationship between teaching competencies and job satisfaction levels of the primary school teachers. Competency of teachers depend more on the training of the teacher and if she gets facilitating environment to work then there is refinement in teaching competency skills. But, seeing the results there does not seem to be any relationship existing between teaching competency and job satisfaction. There is also no significant difference between teaching competency level and high, average and low levels of job satisfaction.

\section{Professional Commitment and Job Satisfaction:}

Professional commitment is positively correlated with job satisfaction. Teachers who are satisfied with their job are more committed towards their profession. As the results show that the relationship between the two is significant. An employee if provided all the satisfactory and pleasing services and facilities, he or she will definitely be more committed towards their profession. Teachers who are happy with their job and working environment will for sure give in their best to the profession fulfilling their duty towards the profession. Professional commitment levels of primary school teachers are not influenced by high , average or low levels of job satisfaction of primary school teachers.

\section{Professional Commitment and Teaching competency:}

Professional commitment and teaching competency have very low positive correlation. Teachers who are committed need not be equally competent in the field as it depends on their training also. And teachers who are competent need no be committed as it depends on their work environment and facilities which assure them to have commitment towards the profession but it is not essential that professional commitment and teaching competency have any relationship with one another or they are dependent on each other.

\section{Summary}

Educational system is the most important among all other social institutions of the society. Each system is made by its employees and can be ranked as good or bad accordingly with the performance of the employee. Educational institutions are also dependent on human resources for there performance. A committed employee 
is an asset to any organization and occupies a more important place in educational institutions, because they are in charge of the future of the nation. Teachers are the main input source of any educational institution and teacher's adequate work and responsibility towards the institution makes it good or bad. Teachers aim is o be a change agent transforming light of knowledge and wisdom, imagination and enlightment. A committed teacher is focused and more involved in her/his profession. At times it is presumed that teachers are committed and devoted to their profession, although this is not always the case. It has been sometimes noted that even though the line of work has been chosen voluntarily by teachers, commitment tend to decrease after sometime. Lower commitment affects the effectiveness of schools and causes teachers to be less successful in their professional performance or to leave the profession in extreme cases. Along with commitment towards the profession teachers also need to be competent in their skills of teaching. Teaching competency Teaching competencies include the acquisition and demonstration of the composite skills required for student teaching like introducing a lesson, fluency in questioning, probing questions, explaining, pace of lesson, reinforcement, understanding child psychology, recognizing behavior, classroom management and giving assignment. Competency development must a continuous process in the organization.

Professional commitment and teaching competency can be seen mostly in relation to job satisfaction acquired by the teachers. Job satisfaction Job satisfaction in the result of various attitudes possessed by an employee towards his job. These attitudes are related with specific factors such as salary, service condition, opportunity, working condition and colleague. In present study, efforts have been made to study the three main aspects of teaching for teacher that is: Professional Commitment, Job Satisfaction and Teaching Competency. The study is done among Primary school teachers in the city of Lucknow.

\section{Educational Implications:}

1. Competent teachers are required in every educational institution so as to increase the effectiveness of the institution, it is necessary to know about professional commitment and how it is influenced by other variables. Teaching competency of the teachers is not dependent on job satisfaction but frequent workshops or interaction with experts can groom the competencies required by the teachers.

2. The present study reveals that commitment is influenced by the work situation and satisfaction of the teachers in those working conditions.

3. School authorities should identify the ways and means through which teachers can be provided with facilitating work environment which will influence their work and also commitment towards teaching. Satisfaction from the job is necessary for full devotion and commitment of teachers towards the profession.

[1]. Avila. (1989). Teaching competencies of secondary school teachers. Sited in fourth survey of educational research by M.B.Buch,2(1), 1016

[2]. Best \& Kahn. (1998). Research in Education. New Delhi : Prentice Hall

[3]. Competency Development sited in Employment News ,28(48) 1-2, Dated Feb28'2004

[4]. Dave, P.N. (1982), Teaching and teacher behavior. Sited in third Survey of Educational Research by M. B. Buch, 772-773

[5]. Desai \& Deshpande. (1996). Effect of feedback on teacher competence. sited in fourth survey of educational research by M.B.Buch, 2

[6]. Edwards, K. (2004). Perceptions of elementary school teachers. Dissertation Abstracts International,65(5),1023

[7]. Gamoran.O.(2003). School effectiveness and school improvement. Sited on www.reload.ac.uk/

[8]. http:/ ucc.edu.gov/

[9]. http:/ www.eric.ed.gov/ERIC WEBPOSTAL

[10]. http:/www.eric.ed.gov/ERIC WEBPOSTAL

[11]. Jha,S.N.(1986). A study of professional commitment of teachers. Unpublished P.hD, University of Lucknow

[12]. Kerlinger, F.N. (1964). Foundation of Behavioral Research. New York: Winston.

[13]. Koul, L. (1998). Methodology of Educational Research. New Delhi: Vikas Publications.

[14]. Kumar \& Maiti ,(2005). A study of professional commitment of secondary school teachers in relation to their value patterns and job satisfaction. Unpublished PhD Thesis, University of Lucknow

[15]. Michalinos \& Zembylas, ( 2006). Sources of teachers job satisfaction and dissatisfaction. Journal of comparative education, 36(2), 229-247

[16]. Miller \& John. (2001). Teachers in transition. Dissertation Abstract International.62(2),1036

[17]. Ramakrishnan,D.(1989). Job satisfaction of college teachers. sited in fifth survey of educational research by M.B. Buch, vol.2,1221

[18]. Singh \& Singh, (2003). A study of teaching competency of primary school teachers. Unpublished PhD thesis, University of Lucknow.

[19]. Smith,H.( 2006). Prospective Teachers. Journal of Educational Technology.22(2),229-50

[20]. Srivastava,S. (1986). A study of job satisfaction and professional honesty of primary school teachers. Unpulished P.hD, Univeristy of Avadh.

[21]. Tracy, K. (2003). Professional Development \& Student learning. Retrieved on sep 12, 2006 from http:/ www.coppercore.org/

[22]. www. edufac.unimelb.edu.ac/arc/teaching 